\title{
METHOD FOR RESERVES DETERMINATION OF STATIC AND DYNAMIC LIST OF BULK CARRIERS, APPLIED TO THE DYNAMIC UNDER KEEL CLEARANCE SYSTEM IN THE PORT OF SWINOUJSCIE
}

\begin{abstract}
The paper presents the methodology for determining the components which are related to heel of bulk carrier with one component excluded - the heel of vessel due to waves. The described method was applied to the system, which is dedicated to use in determination of UKC of vessels at the approach to the Port of Swinoujscie. The method includes determination of heel caused by: draught reading errors, wind, current, tugboats and heel related to vessel maneuvers. To determine heel related to vessel maneuver 2-stage method was carried out. The first stage simulation was used to identify the parameters of ship movement. At the second stage, the maximum heel of Bulk Carrier were calculated by using analytical methods. Presented method was implemented to the item rating under keel clearance at the approach to the Port of Swinoujscie
\end{abstract}

\section{Keywords:}

bulk carrier, dynamic UKC, simulation methods, analytical methods, heel, pressure transmitters.

\section{INTRODUCTION}

Inspection of vessel draught, list and heel is the basis to conduct safe operation of the vessel. In the areas where the under keel clearance is limited those components must be taken into the close consideration. Apart from the aspect of 
the navigational safety, it is mainly about pure economics. Knowledge of the available under keel clearance directly affects the amount of carried cargo. Shallow water areas, same like close proximity to the various navigational dangers, must be closely analysed while passage planning. It should be noted the 'shallow water' is a relative term, largely dependent on the size of the vessel which navigates within such areas. The shallow waters, which are known as restricted water areas, include among other harbours, dredged fairways, straits, river and sea channels [Nowicki, 1999].

To indicate vessel's under keel clearance the following data must be well thought out:

- width and available depth of the waterway;

- density of water;

- tides value;

- vessel LOA and breadth;

- vessel draught and displacement;

- vessel squat;

- weather conditions: wave height, wind speed and direction.

There are many different variables which has influence over vessel's under keel clearance. It is very important to determine the vessel draught, list and heel with the utmost precision, which presently might be identified by various method. Ability to estimate those values correctly is crucial to provide proper exploitation of the vessel in view of navigational and economical aspects.

\section{SYSTEMS AND METHODS OF VESSEL DRAUGHT, LIST OR HEEL IDENTIFICATION AND THEIR ACCURACY LEVEL}

One of the most important measurements made on the vessel concern draught and list. On their basis, the stability of the vessel is determined. Nowadays, to indicate vessel draught or list comparison of those values taken from several separate and independent sources must be made.

Due to the nature of their accuracy, the readouts of measuring equipment are continuous.

Comparison values of vessel draught and list readout from draught marks and cargo loading program is the most popular method of its identification. Those readings are considered as the most reliable. 


\section{Draught marks}

The accuracy of draught identification depends mainly on officer experience and sea state at the moment of reading. Although it is the oldest method, still recognized as the one of the most accurate, which gives the real value of vessel draught.

Determining the vessel list or heel from draught marks located at the midship has a disadvantage. This is necessity to take the draught readouts from both sides of the hull at the same time. Due to that inconvenience the method is used in most cases while vessel is in shipyard or alongside.

\section{Cargo loading software}

Nowadays cargo loading software is used as a main source of information to control stability of the vessel. It must be remembered that only accredited by oficial maritime classifiers software can be considered as a reliable source. Proper calibration allows to get readouts with an accuracy of less than $1 \mathrm{~cm}$ only if the rest of specific vessel data are indicated correcly for example the direct amount of diesel, HFO, LSFO, fresh water etc.

\section{Pressure transmitters}

Draught measuring system is designated to measure and control the draught of vessels during cargo operation and voyage at low speed. One of the most important factors in evaluating draught, trim and list are obtained from submerged measure points, located on the bow, stern part of the hull, and also symmetrically both sides at midship. Signal generated from those four points indicate draught and horizontal position. Unfortunately those readouts are inaccurate with an error up to $5 \mathrm{~cm}$ on the beginning, increasing over time. There are different pressure transmitters with diverse accuracy currently available on the marine market. Table 1 presents selected products with the relative narrow measure error.

Tab. 1. Summary of accuracy level of selected pressure transmitters

\begin{tabular}{cccc}
\hline Manufacturer & Product & Accuracy & Source \\
\hline VEGA & VEGAWELL52 & $<0,1 \% \mathrm{FR}$ & Vega Grieshaber KG (2015) \\
APLISENS & APR-2200ALW & $\pm 0,1 \% \mathrm{FR}$ & Aplisens S.A.(2015) \\
BARKSDALE & UPA2-LMK-457-GL & $0,25 \% \mathrm{FR}$ & Barksdale GmbH(2016) \\
KONGSBERG & GT403 & $<0,25 \% \mathrm{FR}$ & Kongsberg Maritime AS (2009) \\
BESI & PESS & $<0,2 \% \mathrm{FR}$ & BESI Armaturen GmbH \& Co KG (2000) \\
A.P.I. Marine & UPT & $0,2 \% \mathrm{FR}$ & A.P.I. Marine ApS (2009) \\
YOKOGAWA & EJA120E & $\pm 0,2 \%$ & Yokogawa Electric Corporation (2015) \\
VALIDYNE & DR800 & $\pm 0,1 \% \mathrm{FR}$ & Validyne Engineering (2015) \\
\hline
\end{tabular}

FR - full range [psi] 


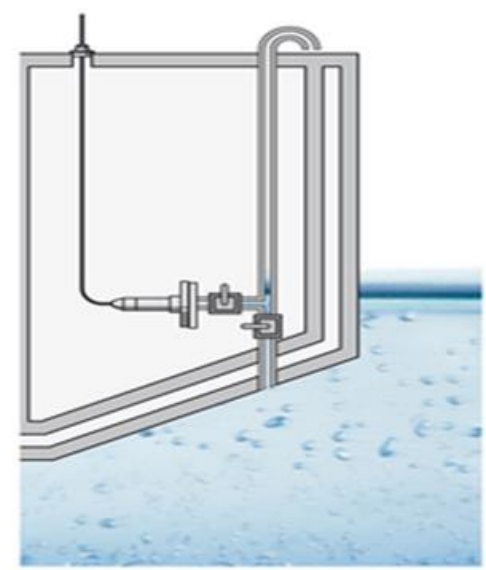

Fig. 1. Typical application schema of pressure transmitter (Vega controls)

\section{Clinometer/Inclinometer}

An clinometer, also known as an inclinometer, is the device used for pointing and measuring the angles of the earth's surface. In the marine industry, inclinometers are used mainly on vessels to measure how much a vessel list while cargo operation or calm sea condition passage. It is known as the most popular and fastest way to identify the vessel list and her stability (Fig. 2). Because of its sensitivity, device is mostly used during harbor loading operations. Due to many different external factors, like: waves caused by other near passing vessels, slack of mooring lines, etc., which can falsify readouts of list, the position of the vessel must be checked continuously.

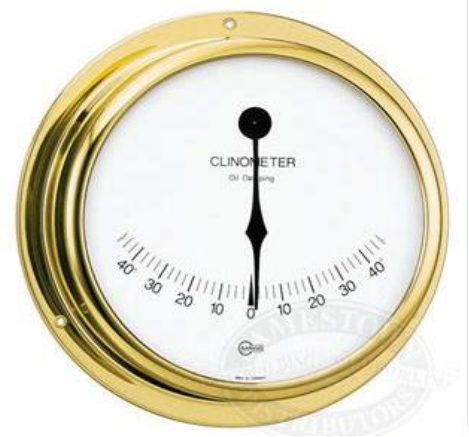

Fig. 2. Typical clinometers [Seashop.eu, Westsea] 
Instead of clinometer, it is very popular to use the mathematical pendulum to monitor the vessel list. It can be home made as a particle of mass connected by a rigid, weightless rod (or a thread) of length to a base by means of a pin joint that can oscillate and rotate.

\section{RESERVE OF CONSTANT LIST OF BULK CARRIER $(\Delta 7)$}

Compensation of possible constant list in practice is done with the use of vessel ballast system. To indicate total list correction factors like: constant list $\Delta 7_{s}$ and heel caused by wind $\Delta 7_{w}$, by current $\Delta 7_{p}$, by vessel turning $\Delta 7_{z}$, by tugs $\Delta 7_{h}$, must be taken into account. The correction models should also include the real states of external environmental conditions (sea state, wind force, currents), because they represent $25 \%$ of total reserve amount.

Constant list $\Delta 7_{s}$

Pressure transmitters fitted at vessel midship, with maximum inaccuracy of $5 \mathrm{~cm}$ makes maximum reserve of constant list not more than $5 \mathrm{~cm}$.

\section{Hell caused by wind $\Delta 7_{w}$}

An accurate description of the environmental forces and moments are important in vessel simulators that are produced for human operators [Fossen, 2011].

The lateral windage area with the height of center point of the wind influence, direction and value of wind force were necessary to determine vessels heel caused by the wind. The following methods can be applied:

- accurate method based on vessel stability data, including her righting lever curves $G Z=\mathrm{f}(\varphi)$ for a given loading condition;

- approximate method for minor vessel heel, where location of her center of gravity $K G$ is necessary to known.

The paper presents calculation for bulk carrier with $13.2 \mathrm{~m}$ draught with the use of accurate method, since all necessary stability parameters are known.

The wind force $F_{w}$ affecting the vessel at a height of $\mathrm{d}_{\mathrm{h}}$, which is counted from water surface, is shown in Figure 3. Wind force lever arm $\mathrm{d}_{\mathrm{w}}$ is calculated for the axis of rotation located between center of gravity $K G$ and the center of buoyancy $K F$ (which is $0,5 \mathrm{~T}$ ). Based on vessel stability data and performed calculations, the correction of vessel heel caused by wind was determined. 


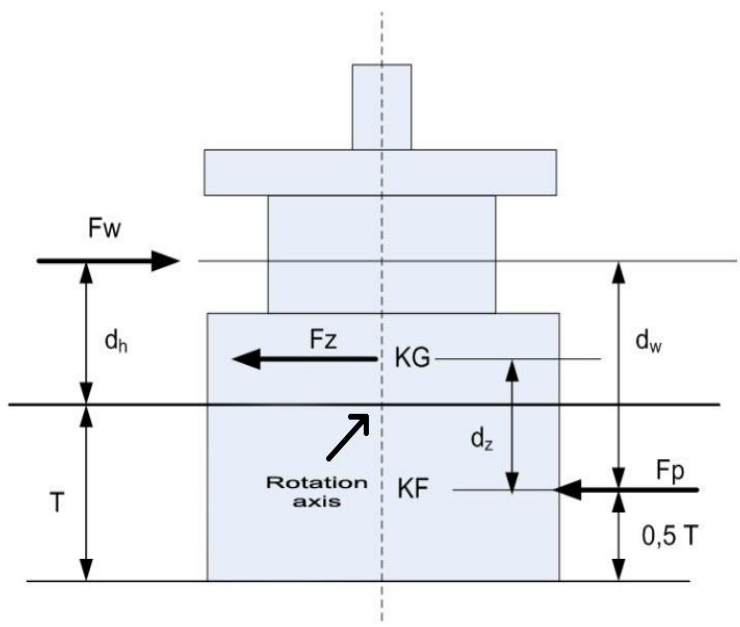

Fig. 3. Parameters used in calculation of vessel heel caused by wind

To calculate the correction of vessel heel caused by wind $\Delta 7_{w}$ following formulas were used:

$d_{w}$ - wind heeling arm:

$$
d_{w}=(T-K F)+d_{h}[m]
$$

$d_{z}$ - distance counted from $K G$ to $K F$ :

$$
d_{z}=d_{w}-K F[m]
$$

$F_{w}$ - wind force ( windage areas shown in fig. 4):

$$
\begin{gathered}
F_{w}=0,5 *\left(\left(P_{w 1} C_{w 1}\right)+\left(P_{w 2} C_{w 2}\right)+\left(P_{w 3} C_{w 3}\right)\right) * \operatorname{rop} * v_{w}{ }^{2}[N] \\
\Rightarrow F_{w}=0,5 * \sum\left(P_{w_{n}} C_{w_{n}}\right) * \operatorname{rop} * v_{w}{ }^{2}[N]
\end{gathered}
$$

$M_{w}$ - wind heeling moment:

$$
M_{w}=F_{w} * d_{w}[\mathrm{Tm}]
$$

$\sin (\varphi)-$ sinus of heeling angle:

$$
\sin (\varphi)=\frac{M_{w}}{G M * D}
$$


$\varphi d$ - dynamic vessel heel:

$$
\varphi d=2 \varphi ;
$$

$\Delta 7_{w}-$ correction of vessel heel caused by wind:

$$
\Delta \mathbf{7}_{\boldsymbol{w}}=\frac{B * \sin (\varphi d)}{2} .
$$

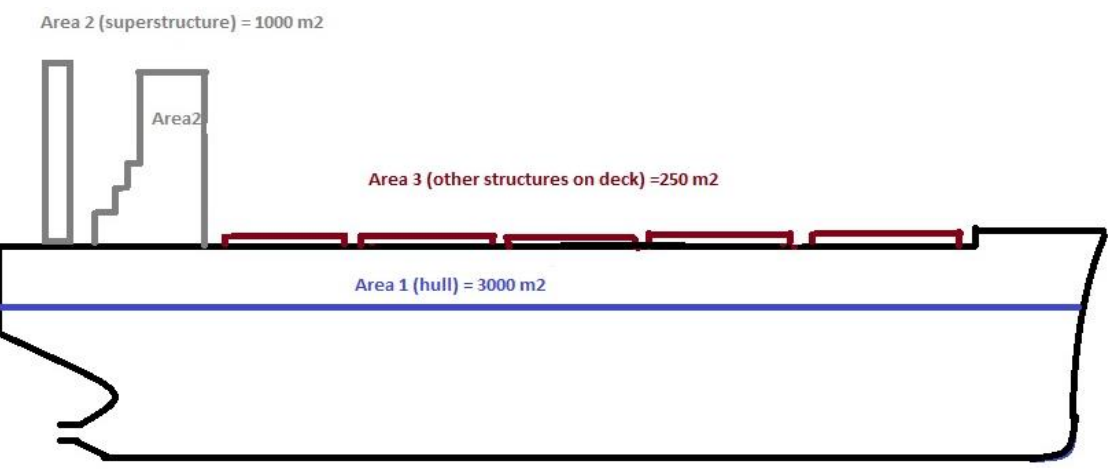

Fig. 4. Lateral windage areas and wind resistance factors of Capesize Bulk carrier applied to calculations

The calculated value of vessel heel caused by wind is only $0,14 \mathrm{deg}$, which gives the correction $\Delta 7$ on the level of $0,06 \mathrm{~m}$.

\section{Vessel heel caused by current $\Delta 7_{p}$}

When the vessel pass the junction of channels, estuary of river, etc., the vessels drift is unstable. Due to strong currents affecting the vessel from varius directions vessel heel caused by current occurs.

It should be noted, that the heeling arm caused by current takes the minimum value. This is because the current force $F_{p}$ affects the hull on the level of axis of vessel rotation, i.e. in the vicinity of the center of buoyancy $K F(K F=0,5 \mathrm{~T})$, therefore it is negligible.

\section{Vessel heel caused by vessel turning $\Delta 7_{z}$}

Calculations described in the paper were carried out on the basis of simulation trials of, which assumed safe entry of Cape size Bulk carrier to the Port of Swinoujscie (Fig. 5). Simulation had been performed in the worst, allowable to enter weather condition. 
Turning at speed could be executed by using rudder. When moving ahead the ship rotates around the pivot point located in the front part of the ship [MacElrevey, 2004].

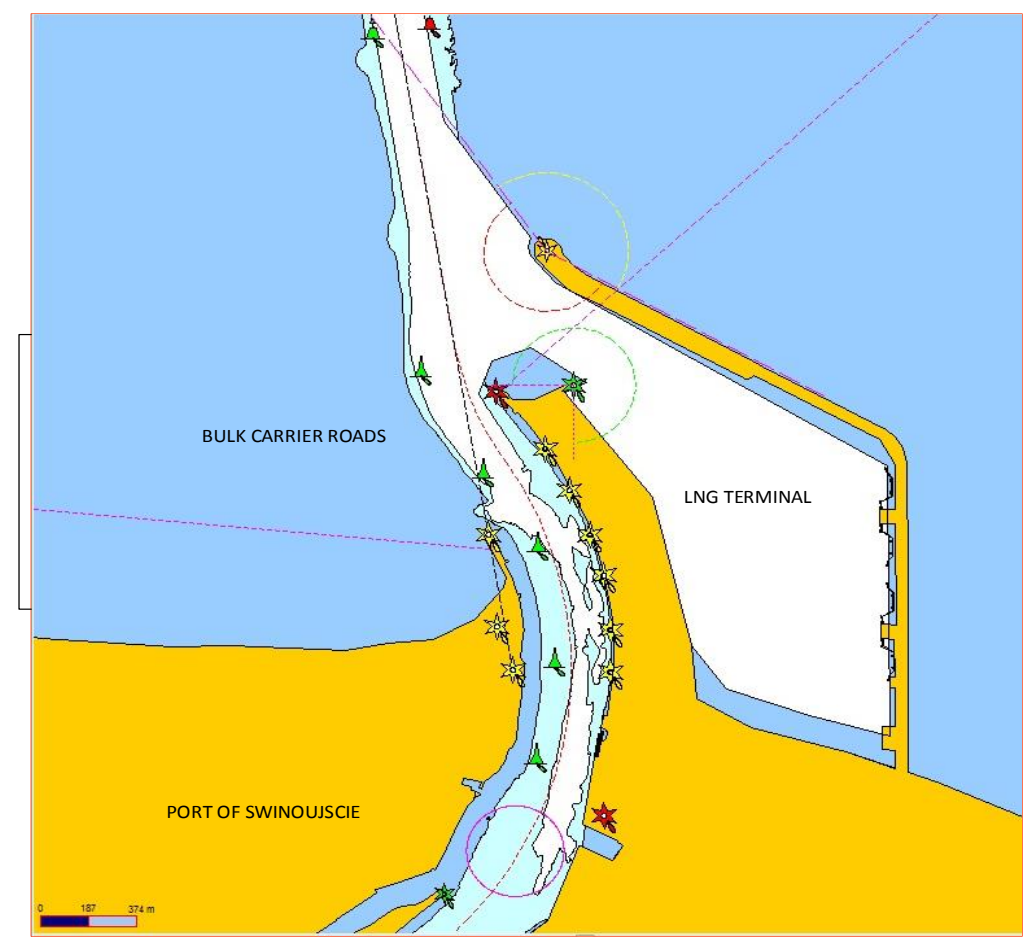

Fig. 5. Bulk carrier fairway to Port of Swinoujscie

Standard deviation of statistical sample $\mathrm{S}$, which contained the rudder angles recorded during vessel approach to bulk carrier roads at charted course170 $\left[^{\circ}\right]$, was calculated using following formula:

$$
S=\sqrt{\frac{\sum(X-\bar{X})^{2}}{n-1}},
$$

where:

$X$ - consecutive number of sample,

$\bar{X}$ - arithmetic average,

$n$ - total number of samples. 
With the use of formula (9), the following was calculated:

$$
\begin{gathered}
S=5.4\left[^{\circ}\right] ; \\
S(0,95)=15.9\left[^{\circ}\right] .
\end{gathered}
$$

The standard deviation calculated for rudder angles with a level of confidence of $95 \%$, can be defined as the interval (Fig. 6):

$$
S(0,95)=(\text { from })-16 \text { (to) } 5\left[^{\circ}\right] .
$$

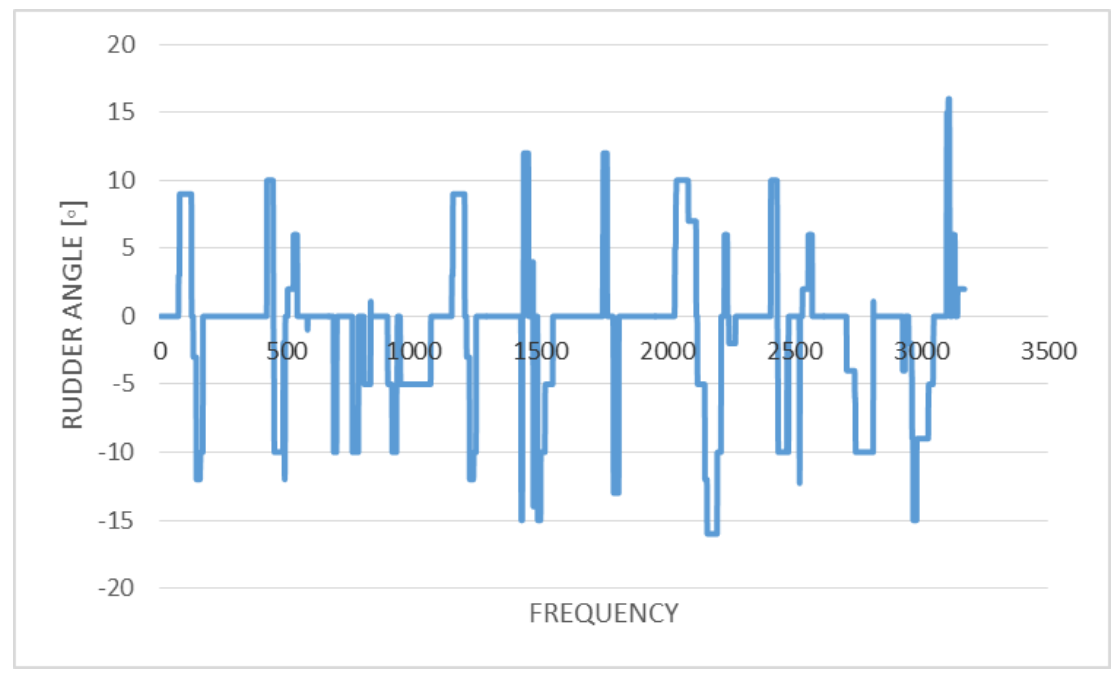

Fig. 6. Rudder angle histogram for Capesize Bulk carrier approaching Port of Swinoujscie

Simulation experiment was carried out to determine the turning circle radius of capesize bulk carrier and was conducted entirely in the multi-purpose marine ship's navigation bridge simulator in the Marine Traffic Engineering Centre located at the Maritime University of Szczecin, Poland. The simulator's software allows for creating model of capesize bulk carrier, basins and weather/ sea conditions to carry out the simulation trials. The trials assumed $180 \mathrm{deg}$ turning to starboard side, for selected rudder angles with start speed of 6 knots. For the purpose of this experiment and finally to calculate reserve of constant list of bulk carrier the tactical diameter of turning circle $D_{t}$ was calculated (Tab. 2 and Fig. 7). 
Tab. 2. Radius of turning circle determination for Capesize bulk carrier

\begin{tabular}{|c|c|c|c|c|c|}
\hline Rudder angle & $\left.\lambda \mathbf{1}^{\circ}{ }^{\circ}\right]$ & $\lambda \mathbf{2}\left[^{\circ}\right]$ & $\boldsymbol{D}_{\boldsymbol{t}}\left[^{\circ}\right]$ & $\boldsymbol{D}_{\boldsymbol{t}}[\mathbf{M m}]$ & $\boldsymbol{R}[\mathbf{m}]$ \\
\hline $\mathbf{5}^{\circ}$ & 14.26121 & 14.28579 & 0.024 & 1.47 & 1365.7 \\
\hline $\mathbf{1 0}^{\circ}$ & 14.26121 & 14.27853 & 0.017 & 1.04 & 962.4 \\
\hline $\mathbf{1 5}^{\circ}$ & 14.26121 & 14.27603 & 0.015 & 0.89 & 823.2 \\
\hline $\mathbf{2 0}^{\circ}$ & 14.26121 & 14.27432 & 0.013 & 0.79 & 728.3 \\
\hline $\mathbf{2 5}^{\circ}$ & 14.26121 & 14.27374 & 0.012 & 0.75 & 695.9 \\
\hline $\mathbf{3 0}^{\circ}$ & 14.26121 & 14.27257 & 0.011 & 0.68 & 630.8 \\
\hline $\mathbf{3 5}^{\circ}$ & 14.26121 & 14.27215 & 0.010 & 0.66 & 607.6 \\
\hline
\end{tabular}

Following formulas were used to calculate tactical diameter $D_{t}$ and radius $R$ of turning circle:

$$
\begin{gathered}
D_{t}=\lambda 2-\lambda 1\left[^{\circ}\right] ; \\
R=\frac{D_{t}}{2}[m] .
\end{gathered}
$$

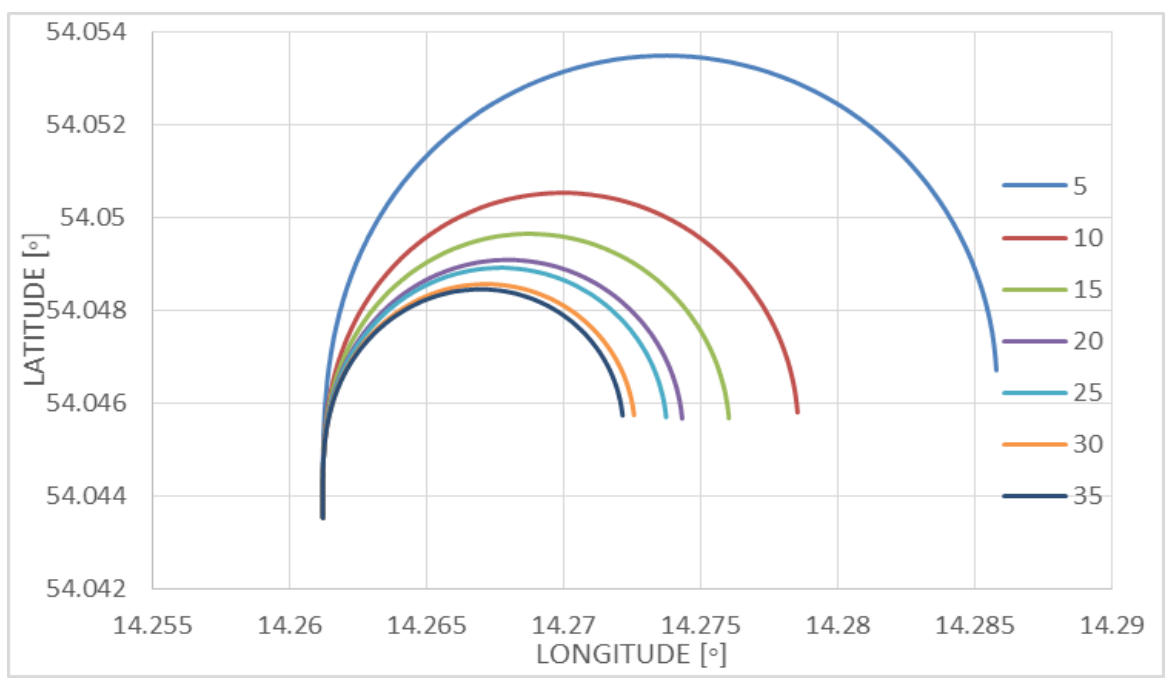

Fig. 7. Diameter of tactical turning circle achieved from simulation passages of Capesize Bulk carrier with rudder angle interval from 5 to $35 \mathrm{deg}$

Some corrections of heading while approach the port can cause the heel of such large vessel. 
Centrifugal force $F Z$ appearing while vessel turns act on the $\mathrm{KG}$ level and take value of:

$$
F_{Z}=\frac{M v^{2}}{R}
$$

where:

$M$ - mass of vessel with water that accompanies,

$v$ - vessel speed while turns,

$R$ - radius of turning circle.

or with the alternative method:

$$
\operatorname{tg}(\varphi)=\frac{v^{2} * F G}{g * R * G M^{\prime}}
$$

where:

$F G$ - distance between vessel center of gravity and center of buoyancy $\left(d_{z}\right.$ parameter),

$G M$ - intact metacentric height,

$R$ - radius of turning circle,

$g \quad$ - gravity.

In practice, the vessel heel is lower, because the contrary inclined rudder counterbalances its value (about 20\%).

If we assume that the vessel makes minor corrections of heading using her rudder up to $10 \mathrm{deg}$, correction of vessel heel caused by her turning can be calculated with following formulas:

$M_{Z}$ - heeling moment:

$$
M_{z}=F_{z} * d_{z}[T m]
$$

$\varphi$ - determination of vessel heel:

$$
\sin (\varphi)=\frac{M_{z}}{G M * D}
$$

or by alternative method (Derret, 1999):

$$
\tan (\varphi)=\frac{V^{2} * d_{z}}{R * G M * g}
$$


$\Delta 7_{z}-$ correction of vessel heel caused by her turning:

$$
\Delta 7_{z}=\frac{\mathrm{B} * \sin (\varphi)}{2} .
$$

Vessel heel caused by tugs $\Delta 7_{\text {h }}$

For the purpose of this calculations it has been assumed, that the vessel heel is caused by thrust of two tugs (emergency situation), which pull the Capesize bulk carrier in direction of $45 \mathrm{deg}$ to vessel centerline.

To determine the correction of vessel heel caused by tugs $\Delta 7_{h}$ the following algorithm was used:

$F_{h}$ - value of lateral force made by tugs:

$$
F_{h}=\sin (k) * U[T]
$$

$d_{f h}$ - distance from point of application to center of buoyancy:

$$
d_{f h}=h_{h}-K F[m]
$$

$M_{h}$ - heeling moment:

$$
M_{h}=F_{h} * d_{f h}[\mathrm{Tm}]
$$

Vessel heel caused by tugs:

$$
\sin (\varphi)=\frac{M_{h}}{G M * D}
$$

$\Delta 7_{h}-$ correction of vessel heel caused by tugs:

$$
\Delta 7_{h}=\frac{\mathrm{B} * \sin (\varphi)}{2}[m] .
$$

Summary of all corrections of Capesize bulk carrier list $-\Delta 7$

Total correction of vessel list $\Delta 7$ can be defined as the summary value of all partial corrections:

$$
\Delta \mathbf{7}=\Delta \mathbf{7}_{s}+\Delta \mathbf{7}_{w}+\Delta \mathbf{7}_{p}+\Delta \mathbf{7}_{z}+\Delta \mathbf{7}_{\boldsymbol{h}}
$$




\section{CONCLUSION}

The paper presents the methods of vessel draught, list and heel determination. All calculations were made for Capesize bulk carrier in the worst allowable to enter the Port of Swinoujscie weather conditions. Calculated total correction of vessel list $\Delta 7$ equals $0,19[\mathrm{~m}]$, what is small value in relation to this size of vessel. On the other hand it can be big value while passing shallow waters areas. It is known that the experience of crew members has a direct impact on the amount of carried cargo (they know how to operate the deep draught vessel). Knowledge of the technology limits of equipment for indicating the level of draught and list or heel is fundamental. Leaving aside the accuracy of measuring devices, for instance pressure transmitters, should be taken into account that their level of its use increases over the time.

The traditional methods of calculations vessel stability are very important elements to determine the draught, list and heel. The following parameters has to be taken into consideration to calculate the value of total list including heel components: draught readouts errors, influence of wind, current and tugboats and hell caused by vessel turnings.

Systematic inspection and calibration of all available on board measuring devices must be conducted, to maintain high accuracy of vessel draught, list and heel readouts both by the official service and vessel officers. Additionally, to decrease possibility of grounding, local regulations in the field of extra value of under keel clearance are implemented by ship owners. The additional UKC is expanded by so called 'margin of safety' and added to the previously calculated UKC.

\section{REFERENCES}

[1] A.P.I. Marine ApS, Data Sheet UPT Universal Pressure Transmitter, 2009.

[2] Aplisens, User's manual, C1 Edition, 2015.

[3] BESI Armaturen GmbH \& Co KG, Besi-PESS, 1st Edition, 2000.

[4] Braksdale, UPA2-LMK 457-GL manual, [online], http://www.marsys.cz/home_htm_files/ba_upa2_dmp_upa2_dmk_upa5_upa2_lmp _upa2_lmk_us_923_0741.pdf [access 14.09.2016].

[5] Derrett D. R., Ship Stability for Masters and Mates, 5th Ed., Butterworth-Heinemann, 1999.

[6] Fossen T. I., Handbook of Marine Craft Hydrodynamics and Motion Control, 1st Ed. Wiley, 2011. 
[7] Kongsberg Maritime AS, Data Sheet Pressure transmitter. GT403, 2009.

[8] Macelrevey D. H., Shiphandling for the mariner, 3rd Edition, Cornell Maritime Press 2004.

[9] Nowicki A., Knowledge to manoeuvre the vessel (in polish), Trademar, Gdynia 1999.

[10] Validyne Engineering, Data Sheet DR800 Draft Range Transmitter, 2015.

[11] VEGA Grieshaber KG, Vegawell52 Operating Instructions, 2015.

[12] www.seashop.eu/clinometer/153-clinometer.html [access 07.02.2016].

[13] www.vegacontrols.co.uk [access 07.02.2016].

[14] www.westsea.com/tsg3/itemlocker/03pixlocker/3-76.JPG [access 07.02.2016].

[15] Yokogawa Electric Corporation, EJA120E Differential Pressure Transmitter Operating Instructions, 2015.

Received October 2016

Reviewed May 2017

Published 29.09.2017

\section{KINGA DRWIEGA}

Maritime University of Szczecin

Wały Chrobrego 1-2 Str., 70-500 Szczecin, Poland

e-mail: k.drwiega@am.szczecin.pl

\section{LUCJAN GUCMA}

Maritime University of Szczecin

Wały Chrobrego 1-2 Str., 70-500 Szczecin, Poland

e-mail: l.gucma @am.szczecin.pl

\section{RAFAL GRALAK}

Maritime University of Szczecin

Wały Chrobrego 1-2 Str., 70-500 Szczecin, Poland

e-mail: r.gralak@am.szczecin.pl

\section{STRESZCZENIE}

W artykule przedstawiono metodykę określania składników związanych z przechyłem Capesize masowca, nie uwzględniając przechyłu od falowania. W metodzie zawarto określenie składowych przechyłu od błędów odczytu zanurzenia jednostki, działania wiatru, prądu, holowników oraz przechyłu związanego z manewrami jednostki. Ostatnia składowa została określona za pomocą metody dwuetapowej. Na etapie pierwszym za pomocą metod symulacyjnych określono parametry ruchu jednostki. Następnie z użyciem metod analitycznych określono maksymalne przechyły masowca. Przedstawioną metodę zaimplementowano do systemu oceny zapasu wody pod stępką na akwenie podejściowym do Portu w Świnoujściu. 